\title{
KuLTURARV SOM HANDLING
}

\author{
John Aage Gjestrum
}

En studie av musealiseringen av Røros viser til ei 100-ärig historie om etablering, omdanning og ny etablering av kulturarv $i$ et lite norsk lokalsamfunn. Det er ikke "objektive" og "autentiske" egenskaper ved kulturarvobjektene som har skapt kulturarven. I stedet er den blitt til (og endret) i et spill der ulike aktører har hatt helt påvisbare nåtidige interesser å ivareta på de aktuelle tidspunkt. Tidsperspektivet viser at det da er helt ulike aktører som på ulike tidspunkt har interesse av à skape kulturarv.

Den 9. august i år åpnes i Norge et gigantisk vernebygg i glass over ruinene etter Hamar domkirke. Bygget er 40 meter høyt, 67 meter langt og har kostet 75 millioner norske kroner. Siden arbeidet med kulturminner i Norge tok fart etter dannelsen i 1844 av Fortidsminneforeningen (Foreningen til Norske Fortidsminnesmerkers Bevaring), har domkirkeruinen på Hamar hatt status som kulturarv - et minne om høgmiddelalderens norske storhetstid. Som kjent tok denne storhetstida slutt, og et av de konkrete uttrykk for dette er nettopp kirkeruinen på Hamar. Under sjuårskrigen gjennomførte en svensk hæravdeling i året 1567 en fullstendig utradering av de norske posisjoner i området og satte domkirken i brann.

Det stolte byggverk fra tida omkring bispedømmets opprettelse i 1152 ble fullstendig ødelagt, og bøndene i området benyttet i et par hundre år framover stein fra kirkebygget til kalkbrenning og egne byggearbeider. Inntil midten av forrige århundre, da minnene fra den tidligere nasjonale storhet ble kul- turarv. Det som da var igjen, var søylerekka etter midtskipets sørvegg.

- Det er det glade vanvidd, sier dekanus og førsteamanuensis Elisabeth Elster $i$ et avisintervju. Hun er kanskje den fremste ekspert i Norge på slike middelalderruiner. Å bygge et slikt glasshus over ruinene er uten mening, det finnes ikke noen faglige grunner til å gjøre dette. Ruinene er gjennomdokumentert og utforsket. All dokumentasjon er sikret for ettertiden og vitenskapen. Så hvorfor bruke 75 millioner på et glasshus?

På tross av betydelig motstand innenfor fagmiljøene er glasshuset på Hamar blitt bygget. Hvis dette ikke skjer som en faglig begrunnet bevaring av kulturarven, hvorfor blir det da realisert?

Er det kulturarven som uttrykk for middelalderens storhetstid, evt. som uttrykk for 1500-tallets norske nederlag overfor svensk overmakt som skal formidles, - eller er arkitekt Kjell Lunds stål og glass-monument med en ruin inni en type nyskapt kulturarv som et (nødvendig?) uttrykk for det norske 1990- 
76 tallets ufattelige store oljerikdom?

Mens historievitenskapen preges av en kontinuerlig pågående kritisk diskurs der alle "sannheter" stadig omprøves og imøtegås av nytolking av autentisk kildemateriale, synes det å være slik at den fysiske kulturarven det vi også kan kalle "historien i landskapet" - innpasses i mytiske fortellinger der kritisk diskurs og autentisk kildeverdi i stor grad synes å forsvinne.

Det synes også å være et grunnleggende karakteristikum ved vår samtid at stadig større deler av det fysiske miljøet gjøres til kulturarv, - musealiseres. Vi ser samtidig et stadig større nostalgi-marked på frammarsj innenfor underholdning, folks fritid, hjeminnredning osv.

Hva er det kulturarven gjør i det nåtidige virkelighetsbilde? Er den under kontroll av et profesjonelt fagmiljø, eller er det slik som Hamar-eksemplet antyder, at kulturarven først og fremst er uttrykk for dominerende krefter i den nåtid som til enhver tid organiserer den?

$\AA$ svare på dette er ikke umiddelbart lett. En måte er å gjøre en konkret studie av hvordan kulturarv har oppstått og kanskje også blitt endret over tid. Den vitenskap som beskjeftiger seg med slike spørsmål er museologien - altså vitenskapen om musealiseringen, om hvordan objekter er tillagt så stor verdi at de skal bevares for all framtid. Dette er imidlertid til nå en vitenskap som befinner seg $\mathrm{i}$ fødestua.

Den kulturarv idag som rangerer med aller størst prestisje er innlemmet på UNESCOs World Heritage List. I alt omfatter den nå omkring 500 objekter spredt over hele verden og med "outstanding universal value", slik UNESCO-konvensjonen fra 1972 formulerer det. Av disse verdensarvobjektene er 18 fra de nordiske land. Fra Norge er det valgt ut fire objekter: Urnes stavkirke (verdensarv i 1979), Bryggen i Bergen (1979), Bergstaden Røros (1980) og helleristningene i Alta (1985). De øvrige nordiske land kom inn på verdensarvlisten gjennom 1990-tallet, - Sverige f.eks. i 1991 med Drottningholm som første kulturarv med status som verdensarv.

Bergstaden Røros er for mange kjent gjennom dikteren Johan Falkbergets skildringer. I sine romaner forteller han om menneskenes kamp med naturkreftene og hverandre i gruvebyen langt oppe på høyfjellet innenfor Trondheim, i grensetraktene mot Sverige. Idag feires Røros som kulturarv, ikke minst med grunnlag i den status det gir å stå på verdensarvlisten.

En studie av musealiseringen av Røros viser at vi gjennom 100 år kan følge en kulturarv under kontinuerlig omdanning. Det er på ingen måte slik at det å være kulturarv er noe som tilligger objekter med bestemte egenskaper, og som så er uendret fra det tidspunkt objektet så er "oppdaget".

Umiddelbart er det også tydelig at denne "omdanninga" skjer etter to helt ulike spor: ett om hvilke objekter som kan inngå i kulturarven, og ett om hva en så faktisk gjør med kulturarvobjektene.

Det første sporet handler altså om defineringen av hva som kan inngå i kulturarven på Røros. I utgangspunktet var det kirken og et av bolighusene i byen med mest særpreget arkitektur. Vi er nå ved forrige århundreskifte. Kunstmaleren Harald Sohlberg malte dengang flere motiver på Røros, malerier som allerede i 1909 fant veien til Nasjonalgalleriet i Oslo. I 1920 fikk Norge en lovgivning for bygningsfredning, og den daværende Riksantikvar satte opp lister over bygninger som skulle fredes. På Røros valgte Riksantikvaren 
ut 5 anlegg, temmelig tilfeldig, ettersom ingen av Riksantikvarens folk besøkte Røros. De hadde imidlertid vært i Nasjonalgalleriet, og husrekken på Sohlbergs bilder ble fredet. På Røros hadde en den gang vanskelig med å forstå begrunnelsene for Riksantikvarens utvalg. Eieren av et av husene fikk da også hevet fredningen av huset, og det ble revet for å flyttes til Norsk Folkemuseum i Oslo.

Omkring 1930 var gruvedriften på Røros nede på et minimum og etableringen av et museum ble lansert som en av lokalsamfunnets strategier for å tiltrekke seg oppmerksomhet. En av initiativtakerne her var nettopp forfatteren Johan Falkberget. Han hadde etter utgivelsen i 1923 av "Den fjerde nattevakt" gjennom 1920-tallet plassert seg tydelig i den norske offentligheten med sine historiske romaner. Rørosmuseet åpnet i $1930 \mathrm{i}$ Åsengården, et av anleggene Riksantikvaren hadde fredet. Etter mye fram og tilbake de neste 4-5 år ble det valgt å bygge opp det permanente museet utenfor Bergstaden som et friluftsmuseum (av Skansen-type). Samtidig overtok museet enkelte små stuer i Bergstaden. Museet profilerte seg med Bergmannsdager der Falkbergets romanfigurer "gjenoppstod" og befolket byen.

Det er nå Riksantikvaren igjen vender seg mot Røros. Denne gang ikke som ledd i en stor og skjematisk massefredning slik det skjedde omkring 1920, men som et laboratorium for utprøving av en ny type miljøbevaring. Gamla Stan i Stockholm var ett av forbildene. Nå er det hele gatepartier som skal bevares, og ikke minst motivene som kan knyttes til Falkbergets dikting. I 1939 inviterer Riksantikvaren hele kulturarvsprofesjonen med Fortidsminneforeningen og museumsforbundet til felles årsmøte på Røros. Nå ble tanken fremmet om at turistnæringen skulle redde gruvebyen på fjellet. Så ble det lagt fram forslag om den mest massive bygningsfredning i Norge til da. Innen kort tid var mer enn 80 bygninger i det lille bysenteret fredet.

Det er nå vi kommer til det vi har kalt det andre sporet i omdanninga av kulturarven. En skulle tro at da Riksantikvaren i 1940 endelig fikk gjennomført den omfattende fredningen, så var det fordi disse bygningene skulle bevares for de egenskaper de hadde som kulturarv. Nei, sier Riksantikvarens medarbeider Halvor Vreim. For å vise det "sanne billede av Røros” må bygningene bygges om: paneling, lister og farger må skiftes ut. Startsignalet gikk for en fullstendig omdanning av bygningene.

Hus etter hus ble ombygget - faktisk eksisterer det idag fredede bygg på Røros der bygningen ble fullstendig revet for å bli erstattet av et helt nytt. Gjennom 25 år ble bygninger gitt nye estetiske uttrykk ut fra en innbilt og mytisk oppfatning av hva som var "ekte" Rørosbygninger. Riksantikvarens eget fotoarkiv viser hvordan de systematisk fjernet bygningenes historiske autentisitet, og gjorde så store inngrep at det etterpå ikke er mulig å se hva som er den gamle og fredede kulturarv, og hva som er tilpassede nybygg.

Vernearbeidet på Røros trengte selvsagt penger. Her fikk en ingen god start, ettersom det var ministerpresident Vidkun Quisling som i 1944 i forbindelse med Røros' 300-årsjubileum raust kunne proklamere det første store statstilskuddet på kr. 250.000. Røros hadde en retorisk kraft som allerede hadde vist seg egnet i Riksantikvarens propaganda i 1939. Quisling ville selvsagt også nyttiggjøre seg dette. Langt senere gjør nok de samme vurderinger om propagandaeffekt seg gjeldende, da Røros - på tross av at en da har erkjent 1940- og 50-tallets feilgrep - blir gjort til 
78 norsk pilotprosjekt innenfor det europeiske arkitekturvernåret i 1975. Herfra viste da også veien seg å være kort til en plass på UNESCOs World Heritage List i 1980.

$\mathrm{Vi}$ skal imidlertid vende tilbake til det vi har kalt det første sporet, - hva som er blitt definert som kulturarv. Røros er det sørligste senteret i Norge for den sørsamiske folkegruppa. I sin kamp for egne skoler og derigjennom en akseptering av sin kulturelle egenart, var det den sørsamiske befolkningen som gjennom 1950-tallet faktisk sterkest greide å prege Rørosmuseets utstillinger og aktivitet.

Det som mest særpreget Rørossamfunnet var naturligvis gruvedriften og bearbeidingen av kobbermalmen. De fysiske anleggene knyttet til dette lå imidlertid helt utenfor kulturarv- og bevaringstenkningen. Det passet rett og slett ikke inn i kulturvernprofesjonens estetiserende tenkesett og forestillingen om bonden som nasjonal kulturbærer. Faktisk var det først på 1970- og 80-tallet at det skjedde en omvurdering av dette synet. På Røros fikk det avgjørende betydning at gruvedriften faktisk ble nedlagt for godt i 1977 , etter 333 års drift. Nå kom den politiske og faglige arbeiderbevegelsen på banen og ville ha en framstilling også av gruvearbeideren. Dette skjedde ved bevaring av Olavsgruva som museumsgruve. Rørosmuseet som friluftsmuseum ble nå faktisk nedlagt og de fleste bygningene flyttet tilbake dit de kom fra. På Malmplassen i sentrum av Bergstaden ble det så bygd et nytt museum som en rekonstruksjon på brannruinene av den gamle smeltehytta. Museumsbygget ble åpnet i 1988 .

Røros-eksemplet viser altså ei 100-årig historie om etablering, omdanning og ny etablering av kulturarv i et lite norsk lokalsamfunn. Det er ikke "objektive" og "autentiske" egenskaper ved kulturarvobjektene som har skapt kulturarven. I stedet er den blitt til (og endret) i et spill der ulike aktører har hatt helt påvisbare nåtidige interesser å ivareta på de aktuelle tidspunkt. Tidsperspektivet viser at det da er helt ulike aktører som på ulike tidspunkt har interesse av å skape kulturarv.

Kulturarven er etter dette først og fremst en sosial konstruksjon, en type handlingsrettet kommunikasjon i ei samtid, - ikke uforanderlige og evige kulturverdier. Røros er idag et pittoresk sted som gir assosiasjoner til århundreder med hard kamp for overlevelse. Som historisk dokument over denne tidsepoken er det imidlertid forfalsket. Derimot gir det en sann beretning om historiske, sosiale og kulturelle brytninger i 1900-tallets Norge, - om konstruksjonen av en kulturarv, - ei historie som kanskje kan være like spennende som den om gruvesamfunnet?

En passende epilog kan være fortellingen om huset som først ble fredet på Røros på 1920-tallet, for så å bli revet og sendt til Norsk Folkemuseum i Oslo. Bygningen går under navnet Per Amundsa-gården, og på tomta etter rivingen av huset på Røros kom det umiddelbart en bensinstasjon. Av det en må regne med er økonomiske årsaker, ble bygningen aldri satt opp igjen på folkemuseet, men ble liggende lagret. Men omkring 1970 var bensinstasjonen nedlagt, og Fortidsminneforeningen greidde å gjenreise Per Amundsa-gården på sin gamle plass i Bergstaden. Det er derfor idag et ganske stort paradoks for kulturarven på Røros som verdenskulturminne, at det anlegg som kanskje er best bevart av de gamle hus på Røros, faktisk er så godt bevart fordi det ble flyttet vekk fra byen før antikvarene begynte å omskape kulturarven!

Et annet og kanskje enda større paradoks er så den neste del av historien: på det stedet Per Amundsa-gården skulle vært gjenreist på 
Norsk Folkemuseum, har museet istedet nå

bygd opp en komplett bensinstasjon fra 1920tallet. Selvsagt sponset av et av de store norske oljeselskaper.

\section{Note}

- Texten skrevs för den svenska tidskriften "Tvärsnitt", där den publicerades i nr 1999/2, s. 42-47, i översättning av Martin Kylhammar. 